\title{
Role of Social Media in Disaster Management in Bangladesh Towards the COVID-19 Pandemic: A Critical Review and Directions
}

\author{
M M Kobiruzzaman \\ Faculty of Modern Languages and Communication \\ Universiti Putra Malaysia (UPM), Malaysia
}

\begin{abstract}
In the 21 st century, social media play an influential role in changing people's lives from multiple viewpoints such as the communication process, teaching and learning system, healthcare sector, marketing, and crisis management. On the other hand, people can use social media to spread fake and disinformation during the emergency period. This review article articulates social media's role in disaster management in Bangladesh towards the COVID-19 pandemic. A content analysis strategy has been exercised to gather data from different sources, including primary, secondary, and available sources. In order to collect data, the author has accessed the open-access journal, online books, newspapers, magazines, government and non-government web portals. The article extends both positive and negative impacts of social media in disaster management in Bangladesh towards the COVID-19 pandemic, based on the data collected from reliable sources. Social media's positive roles in the COVID-19 pandemic are practising citizen journalism, creating social awareness, maintaining communication in the emergency period, optimise recovery activities, and enhancing charitable donation. In contrast, social media's negative impacts are spreading fake, false, and fabricated news regarding the coronavirus. In conclusion, Based on the discussion and evidence of the previous research result, some recommendations have been presented, such as educating people, focusing on account authentication, and enhancing government responsibilities to prevent the negative role of social media that can reduce the adverse part of social media platforms in the emergency period in Bangladesh.
\end{abstract}

Keywords: Social Media, Disaster Management, Crisis, Bangladesh, COVID-19 Pandemic.

*Corresponding author: M M Kobiruzzaman; Email: mmkobiruzzaman@gmail.com DOI: https://doi.org/10.37227/IJEKM-2021-03-39

\section{Introduction}

The emergence of social media has evolved people's lifestyles in many ways, including the communication system, attitudes, behaviour, relationship, entertainment, economy, education, and so more (Abbas, Aman, Nurunnabi \& Bano, 2019; Duffett, 2017). Social media have both positive and negative implications for the human being, although they have been invented to use only for people's prosperity (Radovic, Gmelin, Stein \& Miller, 2017; Kobiruzzaman, Waheed, Yaakup, \& Osman, 2018). Undoubtedly, it is a great blessing of technology to bring magnificent change in life and ease the communication system. Kobiruzzaman, et al., (2018) articulated that social media, including Facebook, Twitter, Instagram, YouTube, LinkedIn, are the vast platforms for sharing knowledge, exchanging ideas, disseminating information. Nowadays, people cannot imagine starting 
the day without using smartphones and checking social media content. A long time ago, people used to start their day with coffee, but now the smartphone has taken over the place of coffee.

Karlsen and Enjolras, (2016) stated that social media are also known as new media that have immensely affected traditional media, including newspapers, magazines, TV, Radio, and so more. They also illustrated that social media, combined with the telecommunication system, affected people's personal, social, and political life. The positive and negative role of social media has been assembled in this paper to get a clear concept of the social media integrated approach. Despite the critics, social media have a tremendous positive impact on the emergency phase in the country. Hence, this article represents social media's positive roles in disaster management in Bangladesh towards the COVID-19 pandemic. Based on the literature review, only a few studies have been conducted on social media's role in disaster management in Bangladesh towards the COVID-19 pandemic. The coronavirus outbreak was declared a worldwide pandemic on March 11 2020, by the World Health Organisation (WHO) (Munster et al., 2020). It is a very sophisticated issue that outbreaks all over the world since 2019. Therefore, the study's primary purpose is to explore social media's positive roles in disaster management in Bangladesh towards the COVID-19 pandemic.

\section{Social Media}

\section{Literature Review}

Social media are computer and application-based networking sites that ease human communication through the internet (Gungor \& Lambert, 2006). Giri and Vats (2019) stated that social media has emerged as the most convenient and famous platform for communication known as new media. People are adopting social media for entertaining, imparting knowledge, sharing information, and communicating with each other. There are many social media types such as Facebook, YouTube, Twitter, WhatsApp, WeChat, Instagram, Zoom, Google meet, TikTok, QQ, Douyin, Sina Weibo, QZone, Snapchat, Reddit, Pinterest, and so more. Nobody can deny social media's positive role in our personal and social life, although they have adverse impacts on society (Brissette, Scheier \& Carver, 2002). Controversially, Friendster is the first social media platform that was emerged in 2002, following LinkedIn in 2003, Flickr in 2004, Facebook in 2004, YouTube in 2005, and Twitter in 2006, Instagram in 2020, and TikTok in 2016 (Garcia, Mavrodiev, \& Schweitzer, 2013). According to "Facebook MAU worldwide 2020" (2020), It is estimated that around 3.8 billion people use social media, yet Facebook is the most popular social media platform. However, another study shows that the total number of social media users is around 4.14 billion globally, including 53 per cent of the world (DataReportal, 2020). According to the statistic report, Facebook has achieved around 2.74 billion active monthly users all over the world, followed by YouTube, Twitter, Instagram, TikTok, and so more (Facebook MAU worldwide 2020, 2020). 


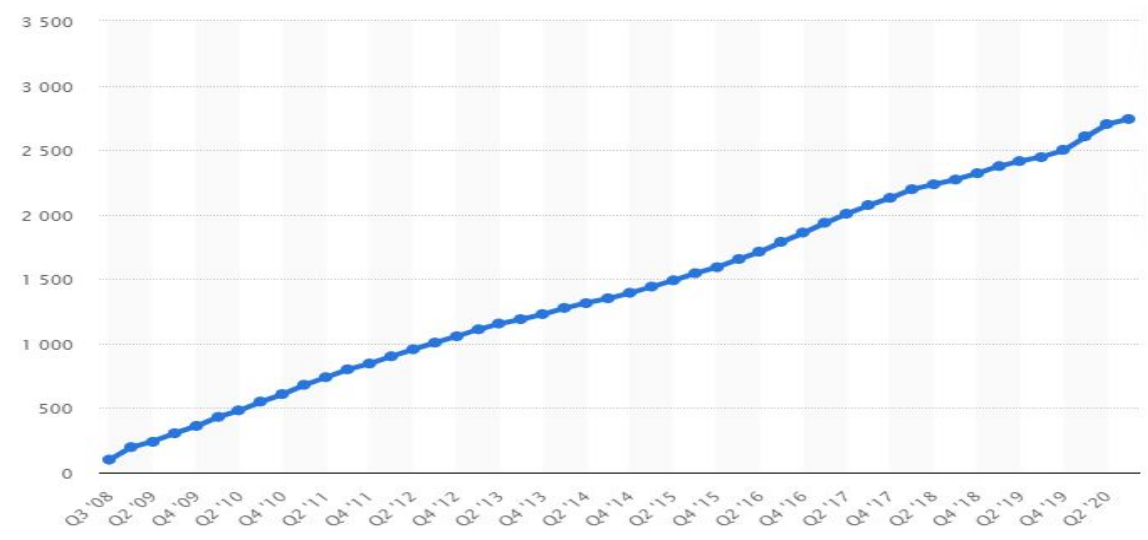

Source: ("Facebook MAU worldwide 2020," 2020)

China ranked first in the top country list with the highest number of internet users, and 854.00 million people use the internet in China (Internet World Stats, 2020). Additionally, Bangladesh ranked 9th in the top country list with 96.00 million active internet users, followed by China, India, U.S.A, Indonesia, Brazil, Nigeria, Japan, and Russia.

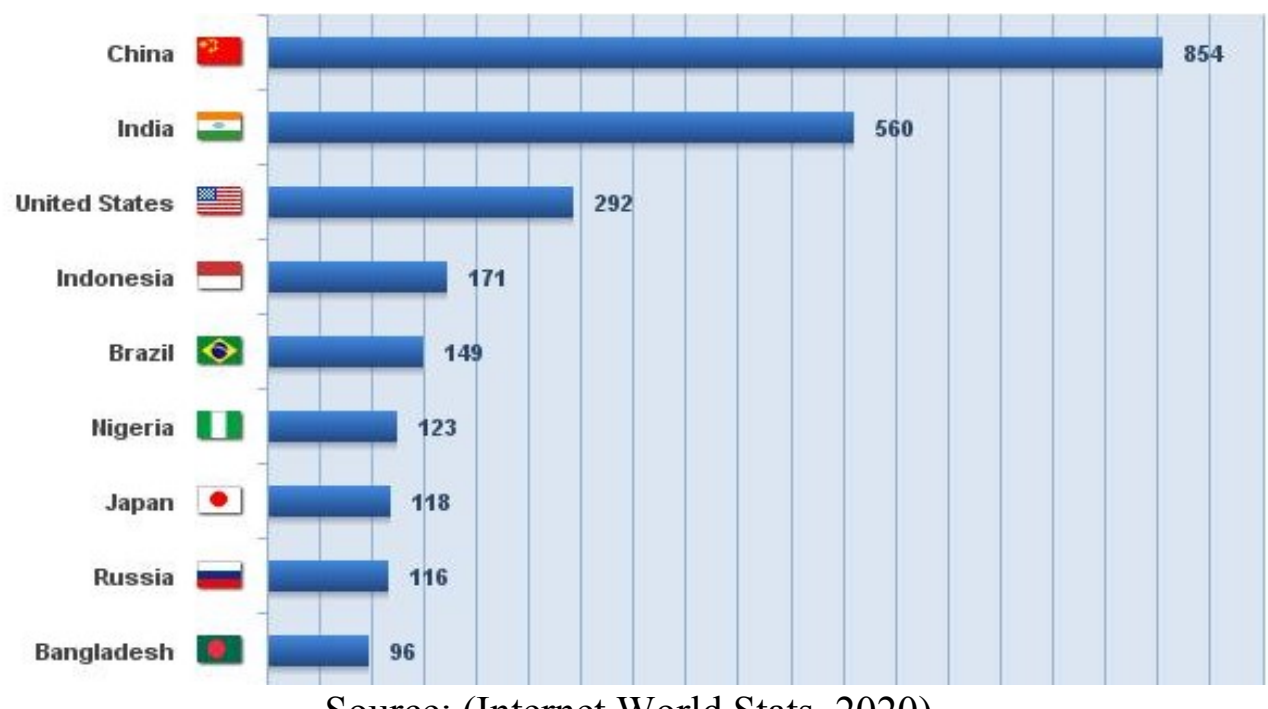

Source: (Internet World Stats, 2020)

\section{Social Media Revolution in Bangladesh}

According to a 2020 study by Telenor, it is calculated that 66.44 million Bangladeshi people are now using the internet that is 41 per cent of the overall population (Digital 2020: Bangladesh, 2020). The most important fact is that 36.0 million people in Bangladesh are using social media in 2020. The internet user has been increased by 5.8 million from 2019 to 2020 . Social media user has been increased by 3.0 million from 2019 to 2020 (Digital 2020: Bangladesh, 2020; Bangladesh - Information and Communication Technology (ICT), 2020). Additionally, social media penetration achieved 22 per cent in 2020. Apart from that, it is approximated that 163.0 million people from Bangladesh are using mobile phones. Like the internet and social media users, the smartphone user has been increased by 7.0 million between 2019 and 2020. However, the mobile user in Bangladesh has achieved $99 \%$ of the population. The most used social media in Bangladesh are Facebook, YouTube, Instagram, WhatsApp, IMO, Zoom, and GoogleMeet. 


\section{Natural Disaster in Bangladesh}

Hassan and Ayub (2015) demonstrated that Bangladesh ranks eighth in the most populous country globally and is highly vulnerable to recurrent natural disasters. Bangladesh is a South Asia country, and it spans 57,320 sq. miles (148,460 Square Kilometres). According to Mondal and Sanaul (2019), Bangladesh's total population has reached 162.0 million by 2018. Thus, Bangladesh has become one of the most densely populated countries on the planet. It shares borders with India, Myanmar, and the Bay of Bengal to the south part. More than 300 rivers, including Padma, Meghna, Jamuna, Brahmaputra, and its branches, make Bangladesh the land of the river (Asian Disaster Reduction Center (ADRC), n.d.). The seashore morphology of Bangladesh increases the adverse impact of natural disasters. Usually, Bangladesh experiences floods, droughts, storm surge, cyclones, riverbank erosion, earthquake, tsunami, and many more minor natural hazards every year. The researchers have identified that floods and cyclones are the most recurrent natural disaster that caused huge damages in Bangladesh. The most recent three cyclones killed 138,866 people in 1991, 4,234 people in 2007, 190 people in 2009, 5 in 2019, and 26 in 2020 respectively (Shoji \& Murata, 2020; AADRC, n.d.). Apart from these cyclones, Bangladesh is encountering many other natural disasters every decade. Table 1 will demonstrates the most devastating disasters in Bangladesh that occurred in the last 30 years.

Table 1: A-List the major disaster in Bangladesh (1990 - 2020)

$\begin{array}{rrrrr}\text { Year } & \text { Nature of Disaster } & \text { Death Toll } & \text { Total Affected People } & \text { Economic Damage } \\ 1991 & \text { Cyclone } & 138,866 & 15,438,849 & 1.780,000 \text { million (USD) } \\ 1995 & \text { Flood } & 400 & 8,000,000 & 175,000 \text { million (USD) } \\ 1996 & \text { Flood } & 33 & 6,163,319 & 150,000 \text { million (USD) } \\ 1998 & \text { Flood } & 1050 & 30,000,000 & 142,160 \text { million (USD) } \\ 2007 & \text { Cyclone } & 4,234 & 8,978,541 & 2,300,000 \text { million (USD) } \\ 2009 & \text { Cyclone } & 190 & 3,935,341 & 270 \text { million (USD) } \\ 2012 & \text { Flood } & 344 & 11,000,380 & 1300 \text { million (USD) } \\ 2013 & \text { (Rana Plaza) Collapse } & 1132 & & \\ 2017 & \text { Flood } & 145 & 8,000000 & \\ 2019 & \text { Cyclone } & 5 & & 385,402,500 \text { BDT } \\ 2020 & \text { Cyclone } & 26 & 26,000,000 & 11 \text { Billion BDT } \\ 2020 & \text { Flood } & 93 & 33,000,000 & 1323 \text { Crore BDT } \\ 2020 & \text { COVID - 19 } & 5861 \text { till now } & 4,03,079 \text { till now } & \end{array}$

Rahman (2010) affirms that Bangladesh's government has invested around \$10 billion to mitigate devastating natural disasters over the last three decades. Furthermore, this immense amount of money has been spent producing climate-resilient crops, flood management schemes, improving warning systems for floods, cyclones, storm surges, and disaster preparation for vulnerable communities. Although mass media are the key contributors to produce and disseminate climate change issues (Rahman, 2010) and they broadcast news to warn people before any upcoming disaster and updating during disaster crises. 
According to ICT (2020), 36.0 million people are using social media that has covered almost 22 per cent of the total population. Social media play an influential role in sending alerts before the disaster in the prospective area. Additionally, it helps to conduct interaction between agency to the agency, Agency to the community, and Community to the community. Social media have both positive and negative roles in disaster crisis management. For example, some people spread fake and baseless information regarding the disaster to operate recovery activities smoothly (Alexander, 2014). Barr (2011) reports that $80 \%$ of the American people and $69 \%$ of social media users believe that social media are essential for disseminating information during disaster crises. In contrast, another researcher said that it would not be a perfect decision to use social networking sites to produce information during an emergency time because it can provide misleading and disinformation.

\section{Methodology}

The research study has been administered based on the data gathered from secondary sources such as journals, newspapers, governmental and non-governmental organisations and books. The content analysis strategy is one of the most used approaches to research social science (Kohlbacher, 2006). The essential steps of a review article's systematic content analysis strategy are planning for the topic, collecting information from authentic sources, coding the data, and finally presenting the results (Bengtsson, 2016). Hence, the author has reviewed the literature from previous studies to collect information relevant to the study's keywords.

In order to ascertain relevant data, the author uses multiple platforms such as Google Scholar, Web of Science, Emerald full text, and Bangladesh government website, worldwide recognised non-government organisation, online news portal, and much more authentic source. Apart from that, the author also uses the following keywords in online search engine: "social media", "social media emergence in Bangladesh", "natural disaster in Bangladesh", roles of social media in disaster management"," role of social media in the COVID-19 pandemic", and "social media-based citizen journalism". Based on the previous result from the literature review, the paper outlined a conceptual framework that demonstrates the positive role of social media in crisis management in the COVID-19 pandemic.

\section{Discussions and Results}

The COVID-19 pandemic has broken the world economy as well as the way of communication. The world health organisation (WHO) proposed all affected countries all over the world to imposed a movement control order (MCO) or lockdown on all affected countries to combat the pandemic (Ashraf, 2020). The government of Bangladesh officially declared a countrywide lockdown on March 262020 (Corona.Gov.Bd., 2021, January 3). However, the first lockdown was imposed at Wuhan city in China on January 132020 (Cheng, 2021, January 8). Bangladesh authorities restricted travelling via water, domestic air, rail, and road (Jahid, 2020). Globally, around 88 million people have been affected by the COVID-19 disease, and it is estimated that around 1.89 million people have died (Cheng, 2021, January 8). In Bangladesh, around 516,019 people have been affected by the coronavirus, where around 7,626 people were died (Corona.Gov.Bd., 2021). Bangladesh has become listed as the 27th among the COVID-19 affected countries globally, and it is estimated that only $0.62 \%$ of Bangladeshi people are affected by the coronavirus disease. 
The use of social media has increased extremely during the COVID-19 pandemic. Many researchers, physicians, celebrities, and political leaders use social media platforms to create social awareness in the COVID-19 pandemic. Regardless of the critics, Social media positively impacts natural disaster crisis management in many perspectives, including driving citizen journalism, creating social awareness, conducting communication, optimising recovery activities, and enhancing charitable donation.

\section{Social Media-Based Citizen Journalism Practicing}

Nowadays, citizen journalism is playing an essential role in the emergency phase in the country. Citizen journalism refers to the general citizen who is playing an influential role in gathering, analysing, reporting, and disseminating news and information (Allan, 2007; Lacy, Duffy, Riffe, Thorson, \& Fleming, 2010). Citizen journalism is also known as democratic journalism, participatory journalism, and street journalism. They collect news and information from different media to share them through social networking sites. Sometimes, they create content paired text with photos and videos to share the opinion to create social awareness. Social media have become the most suitable platform for citizen journalism. Barnes (2012) describes that the primary difference between traditional journalism and citizen journalism is news publishing's systematic procedure. From citizen journalism, a systematic and official procedure must need to maintain for publishing news.

In contrast, a citizen journalist is a freelance journalist who can publish news through social media without following any official procedure. Shearer (2018) argued that $43 \%$ of American people consume news from news social networking sites or social media, and $49 \%$ of adults get news from television. He also mentions that only $16 \%$ of people depend on the print newspaper to get news. The report by "It's good to be connected" (2017) identifies that "When done right, social media can be a force for upholding human rights - we have seen citizen journalism through Facebook and Twitter create movements and raise awareness in ways that would not be possible through conventional media". In Bangladesh, people are getting more dependent on social media day by day for social, economic, educational, and recreational needs. Based on the discussion, it is safe to say that citizen journalism plays a much better role to mitigate natural disaster crisis management in Bangladesh.

\section{Social Awareness}

Social media are ideal platforms for interaction where people can share opinions and meet quickly (Mavrodieva, Rachman, Harahap \& Shaw, 2019). Mavrodieva et al., (2019) found that the top political leader on the planet, including Obama and Trump to Xi Jinping, uses social media to pass their social, personal, and political messages. These messages help tremendously to form a public opinion among followers and general people. Apart from political leaders, celebrities apply social media to disseminate information to create social awareness. The World Health Organisation (WHO) optimises social media platforms, including Facebook, Twitter, and TikTok, to create social awareness regarding the COVID-19 pandemic (Jha,2020; Kobiruzzaman, 2021, March 6). Many celebrities, researchers, physicians, and political leaders work together to create social awareness through social media platforms to combat the pandemic. UNICEF (2020) reported that Mushfiqur Rahim, a famous cricketer in the Bangladesh cricket team, has used his Facebook account, a popular social media platform in Bangladesh, to urge people to stay home during the COVID-19 pandemic. They also mentioned that the Bangladesh cricket 
team had donated the 15-day salary to the COVID-19 fund organised by Bangladesh's government.

Many other celebrities have posted their social media to create awareness among people concerning pandemic along with cricket players. They also indicate what to do and what not to do during this emergency time. In a nutshell, undoubtedly, social media have become the best option to create social awareness in 2020 .

\section{Emergency Communication}

Ahmed (2011) proposed the three crucial dimension of communication between disaster management authorities and communities such as the interaction between agency to the agency (called A - A interaction), Interaction between Agency to the community (called A-C interaction), and Interaction between Community to the community (called, C - C interaction). Firstly, agencies need to communicate with other agencies for getting information and resource sharing. The primary purpose of conducting effective interaction between agency and agency is coordination and collaboration to lessen losses. Many agencies have a social media page (Facebook page, Twitter page, Instagram page, LinkedIn page) to provide information. Sometimes they use other agencies' information to conduct disaster crisis management operations. Secondly, most of the disasters have extremely adverse consequences on human lives as well as society (Ahmed, 2011). In order to mitigate the adverse outcomes from disasters, It is very important to provide up-todate information those required to deal with the disaster (Godschalk, 2003; Shah, Ye, Abid, Khan, \& Amir, 2018; Ahmed, 2011). It is also necessary to educate people to build a resilient community to overcome disasters with proper utilisation of the resources.

A long time ago, disaster management authorities are used to organise workshops and seminars to educate people on how to utilise their resources to mitigate the crisis. Nowadays, these agencies apply social networking sites to educate people effectively. For example, in 2020, the world top-ranked agencies including UN, UNICEF, WHO, and BRAC are actively proving updated information concerning the COVID-19 pandemic. The prime purpose of these agencies is to inform people about the adverse consequences of the COVID-19 pandemic and how to stay safe and ensure others' safety. U (2018) proposed that the four prime segments of the disaster management cycle are Mitigation, Preparation, Response, and Recovery. Disaster management agencies need to ensure effective interaction with the communities at every stage of the four disaster management cycle to reduce casualties. In sum, Social media help tremendously to conduct a simultaneous interaction between agencies and communities to provide alerts, warnings, and relief among affected people.

Finally, Interaction between Communities to the community (called $\mathrm{C}-\mathrm{C}$ interaction) is one of the most significant dimensions. For example, community people need to maintain effective interaction to stay connected during the mitigation cycle. According to the two-step flow theory, the news disseminated via a gatekeeper, the social and political leader of the respective zone (Schach, 2018). Social media are the easiest and convenient way to interact between community to community (Lin, Spence, Sellnow \& Lachlan, 2016). In 2020, people enjoyed the blessing of social media to communicate with each other via social media, including Facebook, Twitter, Zoom, Google meets, WhatsApp, and so more. The COVID-19 pandemic bars physical meeting, so people adopt social media platforms to communicate inside and outside communities.

International Journal of Education and Knowledge Management (IJEKM) 


\section{Optimising Recovery Activities}

Simon, Goldberg and Adini (2015) write that social media and social networking sites have become virtual channels for communication in emergencies such as floods, cyclones, storms, earthquakes, and so more. Effective communication has become a very important factor to conduct organizational operation smoothly in the COVID-19 pandemic. Lack of remote working experience of the employee has influenced many organizations to stop their operation in the COVID-19 Pandemic (Islam, Igwe, Rahman \& Saif, 2020). Therefore, many government and non-government organisations use these social media activities to regulate collaborative communications. The main objective of this collaborative communication is to optimise recovery activities together. Facebook, also the most popular social media globally, has launched its safety check option during the COVID-19 pandemic. Bangladesh governments and non-government agencies use social media platforms to optimise recovery activities during the COVID-19 pandemic. They utilise social media to collect updated information from remote areas and conduct recovery activities based on the information.

\section{Enhancing Charitable Donation}

Social media play an essential role not only to create social awareness but also in collecting charitable donation. People get motivated by social media to donate, and they also like to share their contributions. For example, Tamim Iqbal, also captain of the Bangladesh cricket team, had announced through his Facebook that the Bangladesh national team will donate a 15-day salary to the government fund to fight against the COVID-19 pandemic("Bangladesh: Celebrities, Youth Resolve to Fight COVID-19", 2020). In a nutshell, many government and non-government organisations had come up with charitable donations, and they announced through social media, including Facebook, Twitter, Instagram, and so more.

Figure 1 has been outlined based on the previous studies to present the positive impact of social media on the COVID-19 pandemic. This conceptual framework demonstrates the five important positive roles of social media to combat the COVID-19 pandemic.

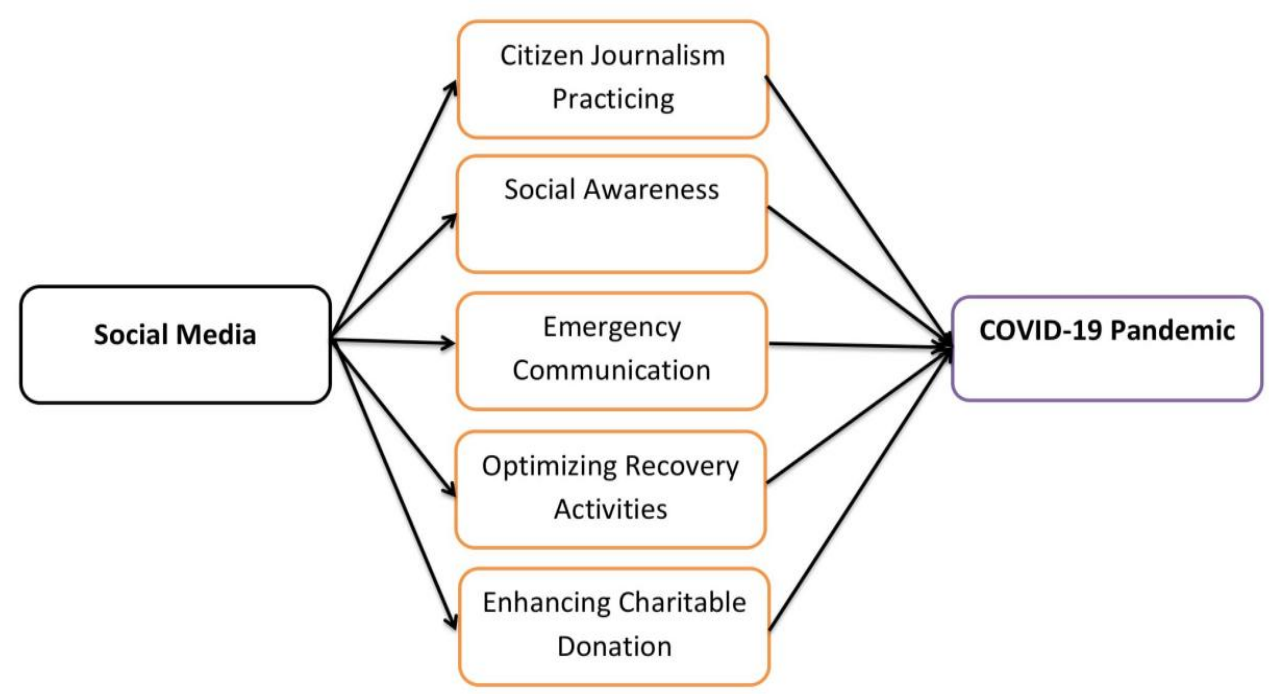

Figure 1: Conceptual Model of Social Media's Role towards COVID-19 Pandemic

International Journal of Education and Knowledge Management (IJEKM) 


\section{Negative Impact of Social Media in Management}

Rashid (2020) mentioned that fake and misleading information is spreading worldwide in the COVID -19 pandemic. Many people have disseminated fake news on social media, including Facebook, Twitter, and YouTube, that homoeopathic medicine can cure coronaviruses. General people have diffused this fake and misinformation concerning coronavirus, and many celebrities are indulged with spreading rumour on social media. Rashid (2020) mentions that many celebrities, including Bollywood superstar Amitabh Bachchan, Indian singer Sonu Nigam, Malayalam TV actress Sadhika Venugopal, and Famous South Indian Superstar, Rajinikanth spread fake news on social media. So, apart from social media's positive impact on disaster management, social media has few adverse consequences in emergencies.

\section{Conclusion and Recommendations}

Based on the data analysis, the author has presented three recommendations, including educating people, focusing on account authentication, and enhancing government responsibilities to prevent social media's negative role. First of all, ensuring proper education on social media is the best way to decrease the negative impact of social media on society. West (2017) mentions that people cannot identify fake news because of not having proper knowledge of social media. He also said that educated people indulge less in spreading fake news through social media than uneducated people. Social media have become an excellent platform for communicating with each other (Bertot, Jaeger \& Hansen, 2012). So, educational institutes should include some lessons regarding the proper use of social media in human's life. Many people do not know how to identify fake news and real news, spreading fake news as believing original news. Bangladesh ranked the fifth position in the internet user in Asia (Report, 2020). Most people are involved in social media, directly or indirectly. These social media influence traditional media to set the agenda and the government to form rules and regulations. Bangladesh government should educate these huge people online or face to face. The negative impact of social media will be decreased when people earn proper knowledge regarding social media. Social media will play a better role in disaster management in Bangladesh towards the COVID-19 pandemic.

Secondly, account authentication is another critical step to prevent the negative impact of social media. Nicas (2019) claimed that Facebook has identified that around 25 per cent of active users are fake. So, 25 people among 100 people are using fake accounts. Most fake accounts are being used to spread misleading information, manipulate data, spread propaganda, and so more. In Bangladesh, 1500, fake Facebook accounts have been blocked within 20 days based on Telecommunication and Information Technology Ministry's application. "Bangladesh has a better relationship with Facebook than before, the technocrat minister said If we ask for something, Facebook's authorities listen to us" (1,500 Facebook accounts blocked in 20 days, 2019). The Facebook authority should be stricter to prevent fake Facebook account. For example, they can compel the user to verify the account with a national ID card or passport. They should also ensure that one person can use only a Facebook account by using fingerprint verifications. Although Facebook has launched its two-step verification system to prevent the account from hacking, this option does not work to stop using fake accounts. People will not use his or her account to spread

International Journal of Education and Knowledge Management (IJEKM) 
fake news if they have a fear of losing account for misapplication. Therefore, strengthening account authentication can play an outstanding role to prevent the negative impact of social media in disaster management in Bangladesh towards the COVID-19 pandemic.

Finally, enhancing government responsibilities contribute immensely to stop the negative impact of social media in disaster management in Bangladesh. Bangladesh's government has to take a zero-tolerance policy to prevent spreading fake news and misleading information. Few fake coronavirus news has been identified in social media that went viral on Facebook. For example, homoeopathic medicine can cure coronavirus disease. Although the Bangladeshi law enforcement agency aware of identifying people who are indulged in spreading fake news regarding coronavirus. According to Report (2020), Bangladesh police arrested a physician for disseminating fake news over coronavirus through Facebook. In an audio clip that went viral on social media, the physician blamed the government for concealing 18/19 deaths from COVID-19. The government should give more opportunities for traditional media to disseminate news smoothly. Sometimes, traditional media such as TV, Radio, and Newspapers cannot disseminate news because of the government's policy, so those policies should be moderated. Many citizen journalists earn money from social media content in Bangladesh. Some of them publish fabricated, fake, and misleading information to get more views. The government should ban those accounts that indulged in miscreant activities. The time has come to conduct a social campaign to create awareness among general people to use social media correctly. Thus, the government can prevent the negative role of social media.

This review paper's overall contents include social media specification, the social media revolution in Bangladesh, and social media contribution to disaster management in Bangladesh. A list of the most devastating disaster in Bangladesh has been outlined with death and property loss. It has assembled both positive and negative social media impacts in disaster management in Bangladesh towards the COVID-19 pandemic. This article has illustrated five positive social media roles, including driving citizen journalism, creating social awareness, operating communication in the emergency period, optimising recovery activities, and enhancing charitable donation. Based on the critical discussion and evaluation of the data, it has been summarised that social media play an imperative role to serve people in many perspectives in any disaster.

\section{Limitations and Direction for Future Research}

This content analysis study has some significant limitations. This article has been developed based on the secondary data analysis approaches; therefore, the primary data has not been assembled. The main finding of the study will help to reduce the literature gap by used in future research. However, some statistic reports can be evolved from time to time.

\section{Biodata}

M M Kobiruzzaman is an international student at the Department of Communication at Universiti Putra Malaysia (UPM). His research interest areas include journalism, human communication, mass media, and social media. He is also a regular writer at Newsmoor.com, an educational website and other educational and news related websites. 


\section{References}

Abbas, J., Aman, J., Nurunnabi, M., \& Bano, S. (2019). The impact of social media on learning behavior for sustainable education: Evidence of students from selected universities in Pakistan. Sustainability, 11(6), 1683.

Ahmed, A. (2011). Use of social media in disaster management. ICIS 2011 Proceedings. 16. https://aisel.aisnet.org/icis2011/proceedings/generaltopics/16

Alexander, D. E. (2014). Social media in disaster risk reduction and crisis management. Science and engineering ethics, 20(3), 717-733.

Allan, S. (2007). Citizen journalism and the rise of "Mass Self-Communication": Reporting the London bombings. Global Media Journal, 1(1), 1-20.

Ashraf, B. N. (2020). Economic impact of government interventions during the COVID-19 pandemic: International evidence from financial markets. Journal of behavioral and experimental finance, 27, 100371.

Asian Disaster Reduction Center (ADRC (n.d.). Asian Disaster Reduction Center ( $A D R C)$. https://www.adrc.asia/nationinformation.php?NationCode $=50$

Bangladesh: Celebrities, youth resolve to fight COVID-19. (2020). AA. https://www.aa.com.tr/en/asia-pacific/bangladeshcelebrities-youth-resolve-to-fightcovid-19/1779034

Bangladesh - Information and Communication Technology (ICT). (2020). International Trade Administration | Trade.Gov. https://www.trade.gov/country-commercialguides/bangladesh-information-and-communication-technology-ict

Barnes, C. (2012). Citizen journalism vs. traditional journalism: A case for collaboration. Caribbean Quarterly, 58(2-3), 16-27.

Barr, P. (2011). Staying connected. Social media put to work when disaster strikes. Modern healthcare, 41(36), 33-33.

Bengtsson, M. (2016). How to plan and perform a qualitative study using content analysis. NursingPlus Open, 2, 8-14.

Bertot, J. C., Jaeger, P. T., \& Hansen, D. (2012). The impact of polices on government social media usage: Issues, challenges, and recommendations. Government information quarterly, 29(1), 30-40.

Brissette, I., Scheier, M. F., \& Carver, C. S. (2002). The role of optimism in social network development, coping, and psychological adjustment during a life transition. Journal of personality and social psychology, 82(1), 102.

Campaign definition and meaning | Collins English Dictionary. (2020, November 20). Collins Dictionaries. https://www.collinsdictionary.com/dictionary/english/campaign

Cheng, E. (2021, January 8). Chinese city near Beijing stops people from leaving as coronavirus cases spike - like Wuhan did last year. CNBC. https://www.cnbc.com/2021/01/07/china-locks-down-part-of-province-outsidebeijing-as-coronavirus-cases-spike.html

Corona.Gov.Bd. (2021, January 3). Coronavirus Disease 2019 (COVID-19) Information Bangladesh | corona.gov.bd. DGHS. https://corona.gov.bd/press-release

DataReportal. (2020). Social Media Users. DataReportal - Global Digital Insights. https://datareportal.com/social-media-users

Digital 2020: Bangladesh. (2020, February 17). DataReportal - Global Digital Insights. https://datareportal.com/reports/digital-2020-bangaldesh 
Duffett, R. G. (2017). Influence of social media marketing communications on young consumers' attitudes. Young Consumers.

Facebook MAU worldwide 2020. (2020, November 3). Statista. https://www.statista.com/statistics/264810/number-of-monthly-active-facebookusers-worldwide/

1,500 Facebook accounts blocked in 20 days. (2019b, February 23). Dhaka Tribune. https://www.dhakatribune.com/bangladesh/nation/2019/02/23/1-500-facebookaccounts-blocked-in-20-days

Garcia, D., Mavrodiev, P., \& Schweitzer, F. (2013, October). Social resilience in online communities: The autopsy of friendster. In Proceedings of the first ACM conference on Online social networks (pp. 39-50).

Giri, D., \& Vats, A. (2019). Social Media and Disaster Management in India: Scope and Limitations. In Smart Technologies and Innovation for a Sustainable Future (pp. 349-356). Springer, Cham.

Godschalk, D. R. (2003). Urban hazard mitigation: creating resilient cities. Natural hazards review, 4(3), 136-143.

Gungor, V. C., \& Lambert, F. C. (2006). A survey on communication networks for electric system automation. Computer Networks, 50(7), 877-897.

Hassan, M., \& Ayub, A. (2015). Role of ICT in natural disaster management of Bangladesh (Doctoral dissertation, BRAC University).

Internet World Stats. (2020). Internet Top 20 Countries - Internet Users 2020. https://www.internetworldstats.com/top20.htm

Islam, M. A., Igwe, P. A., Rahman, M., \& Saif, A. N. M. (2020). Remote working challenges and solutions: Insights from SMEs in Bangladesh during the COVID-19 pandemic. International Journal of Quality and Innovation.

It's good to be connected. (2017, April 15). Dhaka Tribune. https://www.dhakatribune.com/opinion/editorial/2017/04/15/its-good-to-beconnected

Jahid, A. M. (2020, April 26). Coronavirus pandemic: 45 districts now under complete lockdown. The Daily Star. https://www.thedailystar.net/online/news/coronaviruspandemic-45-districts-now-under-compete-lockdown-1896967

Jha, L. (2020, March 19). Coronavirus: WHO, others tap social media, celebs to raise awareness. Mint. https://www.livemint.com/news/india/coronavirus-who-otherstap-social-media-celebs-to-raise-awareness-11584611973037.html

Karlsen, R., \& Enjolras, B. (2016). Styles of social media campaigning and influence in a hybrid political communication system: Linking candidate survey data with Twitter data. The International Journal of Press/Politics, 21(3), 338-357.

Lacy, S., Duffy, M., Riffe, D., Thorson, E., \& Fleming, K. (2010). Citizen journalism web sites complement newspapers. Newspaper research journal, 31(2), 34-46.

Lin, X., Spence, P. R., Sellnow, T. L., \& Lachlan, K. A. (2016). Crisis communication, learning and responding: Best practices in social media. Computers in Human Behavior, 65, 601-605.

Kobiruzzaman, M. M. (2021, March 6). COVID-19 Pandemic Impact- History Background of Coronavirus. Newsmoor- Educational Website For Online Learning. https://newsmoor.com/covid-19-pandemic-impact-history-background-ofcoronavirus/ 
Kobiruzzaman, M. M., Waheed, M., Yaakup, H. S. B., \& Osman, M. N. (2018). Impact of Social Media Towards Society, A Case Study on Teenagers. International Journal of Education and Knowledge Management 1(3), 1-12. https://doi.org/10.37227/IJEKM-03-2018-14

Kohlbacher, F. (2006). The use of qualitative content analysis in case study research. In Forum Qualitative Sozialforschung/Forum: Qualitative Social Research, 7(1), pp. 1-30). Institut für Qualitative Forschung.

Mavrodieva, A. V., Rachman, O. K., Harahap, V. B., \& Shaw, R. (2019). Role of social media as a soft power tool in raising public awareness and engagement in addressing climate change. Climate, 7(10), 122.

Mondal, M., \& Sanaul, H. (2019). The implications of population growth and climate change on sustainable development in Bangladesh. Jàmbá: Journal of Disaster Risk Studies, 11(1), 1-10.

Mican, D., Sitar-Tăut, D. A., \& Mihuţ, I. S. (2020). User Behavior on Online Social Networks: Relationships among Social Activities and Satisfaction. Symmetry, 12(10), 1656.

Munster, V. J., Feldmann, F., Williamson, B. N., Van Doremalen, N., Pérez-Pérez, L., Schulz, J., ... \& De Wit, E. (2020). Respiratory disease in rhesus macaques inoculated with SARS-CoV-2. Nature, 585(7824), 268-272.

Nicas, J. (2019, January 30). Does Facebook Really Know How Many Fake Accounts It Has? The New York Times. https://www.nytimes.com/2019/01/30/technology/facebook-fake-accounts.html

Radovic, A., Gmelin, T., Stein, B. D., \& Miller, E. (2017). Depressed adolescents' positive and negative use of social media. Journal of adolescence, 55, 5-15.

Rahman, M. (2010). Climate change coverage on the mass media of Bangladesh. Global Media Journal, 3(I).

Rashid, A. (2020, March 30). Coronavirus: Celebrities Are Helping COVID-19 Misinformation Go Dangerously Viral Online. NDTV Gadgets 360. https://gadgets.ndtv.com/social-networking/features/coronavirus-covid-19celebrities-spreading-misinformation-social-media-twitter-facebook-whatsapp2202851

Report, T. (2020, July 14). Infodemic amid pandemic: A Bangladesh perspective. The Business Standard. https://tbsnews.net/thoughts/infodemic-amid-pandemicbangladesh-perspective-105976

Schach, A. (2018). Von Two-Step-Flow bis Influencer Relations: Die Entwicklung der Kommunikation mit Meinungsführern. In Influencer Relations (pp. 3-21). Springer Gabler, Wiesbaden.

Shah, A. A., Ye, J., Abid, M., Khan, J., \& Amir, S. M. (2018). Flood hazards: household vulnerability and resilience in disaster-prone districts of Khyber Pakhtunkhwa province, Pakistan. Natural hazards, 93(1), 147-165.

Shearer, E. (2018, December 10). Social media outpaces print newspapers in the U.S. as a news source. Pew Research Center. https://www.pewresearch.org/facttank/2018/12/10/social-media-outpaces-print-newspapers-in-the-u-s-as-a-newssource/

Shoji, M., \& Murata, A. (2020). Social Capital Encourages Disaster Evacuation: Evidence from a Cyclone in Bangladesh. The Journal of Development Studies, 1-17. 
Simon, T., Goldberg, A., \& Adini, B. (2015). Socializing in emergencies-A review of the use of social media in emergency situations. International Journal of Information Management, 35(5), 609-619.

UNICEF. (2018, May 1). Disaster Management 101: Companies, Services and Prevention Tips. Disaster Rally. https://disasterrally.com/disaster-management-101-companiesservices-and-prevention-tips/

UNICEF. (2020). UNICEF names cricket star Mushfiqur Rahim as a new National Ambassador for children's rights. https://www.unicef.org/bangladesh/en/pressreleases/unicef-names-cricket-star-mushfiqur-rahim-new-national-ambassadorchildrens-rights

West, D. M. (2017, December 18). How to combat fake news and disinformation. Brookings. https://www.brookings.edu/research/how-to-combat-fake-news-anddisinformation/

Vartanian, T. P. (2010). Secondary Data Analysis. Oxford University Press. 